\title{
Generation of Skin Organoids: Potential Opportunities and Challenges
}

\author{
Hui Sun ${ }^{1,2,3}$, Yi-Xuan Zhang ${ }^{1,2,3}$ and Yu-Mei Li $^{1,2,3 *}$ \\ ${ }^{1}$ Institute of Regenerative Medicine, Affiliated Hospital of Jiangsu University, Jiangsu University, Zhenjiang, China, ${ }^{2}$ Department of \\ Dermatology, Affiliated Hospital of Jiangsu University, Jiangsu University, Zhenjiang, China, ${ }^{3}$ School of Medicine, Jiangsu \\ University, Zhenjiang, China
}

Although several types of human skin substitutes are currently available, they usually do not include important skin appendages such as hair follicles and sweat glands, or various skin-related cells, such as dermal adipocytes and sensory neurons. This highlights the need to improve the in vitro human skin generation model for use as a tool for investigating skin diseases and as a source of cells or tissues for skin regeneration. Skin organoids are generated from stem cells and are expected to possess the complexity and function of natural skin. Here, we summarize the current literatures

OPEN ACCESS

Edited by:

Philip lannaccone, Northwestern University,

United States

Reviewed by: Johannes Boltze, University of Warwick,

United Kingdom

Lon J Van Winkle,

Rocky Vista University, United States

*Correspondence: Yu-Mei Li

yumeili@ujs.edu.cn

Specialty section:

This article was submitted to

Stem Cell Research,

a section of the journal

Frontiers in Cell and Developmental

Biology

Received: 14 May 2021

Accepted: 21 October 2021

Published: 04 November 2021

Citation:

Sun H, Zhang Y-X and Li Y-M (2021)

Generation of Skin Organoids:

Potential Opportunities and Challenges.

Front. Cell Dev. Biol. 9:709824. doi: 10.3389/fcell.2021.709824 relating to the "niches" of the local skin stem cell microenvironment and the formation of skin organoids, and then discuss the opportunities and challenges associated with multifunctional skin organoids.

Keywords: skin organoid, skin stem cell niches, 3D culture, single-cell RNA sequencing, skin generation

\section{INTRODUCTION}

The skin is a very complex organ that comprises various stem cell populations as well as numerous other cell types (Clevers et al., 2014; Chen et al., 2018). The skin plays an essential role in maintaining the stability of the body's internal environment, protecting the body from daily attrition, and regulating the body's temperature and perception. The outer boundary of the skin, known as the epidermis, is maintained by epidermal stem cells that reside in the basal layer, while the dermis, the layer under the epidermis, is rich in dermal fibroblasts that produce extracellular matrix components, such as collagen and elastic fibers, that give the skin its elasticity. Under the dermis lies subcutaneous fat, which functions as padding, insulation, and energy storage (Takeo et al., 2015; Gravitz, 2018). However, the current in vitro-generated skin models lack many of the normal and necessary skin structures, so we should find new alternative cells and functional models for skin diseases and regeneration.

The continuous and rapid development of stem cell biology can provide new insights into the basic biology of human diseases, thereby driving innovation in the diagnosis and treatment of a variety of conditions. Human pluripotent stem cells (hPSCs), including human embryonic stem cells (hESCs) and human induced pluripotent stem cells (hiPSCs), have become a valuable tool for modeling human diseases, complementing traditional animal research models (Takahashi and Yamanaka, 2006; Takahashi et al., 2007; Shi et al., 2017). Under specific induction conditions, hPSCs can differentiate into any cell or tissue type of the human body. They can also be used to generate threedimensional (3D) in vitro models, i.e., organoids, containing various cell types that can be used for modeling organogenesis and developmental disorders (Dutta et al., 2017; Rossi 


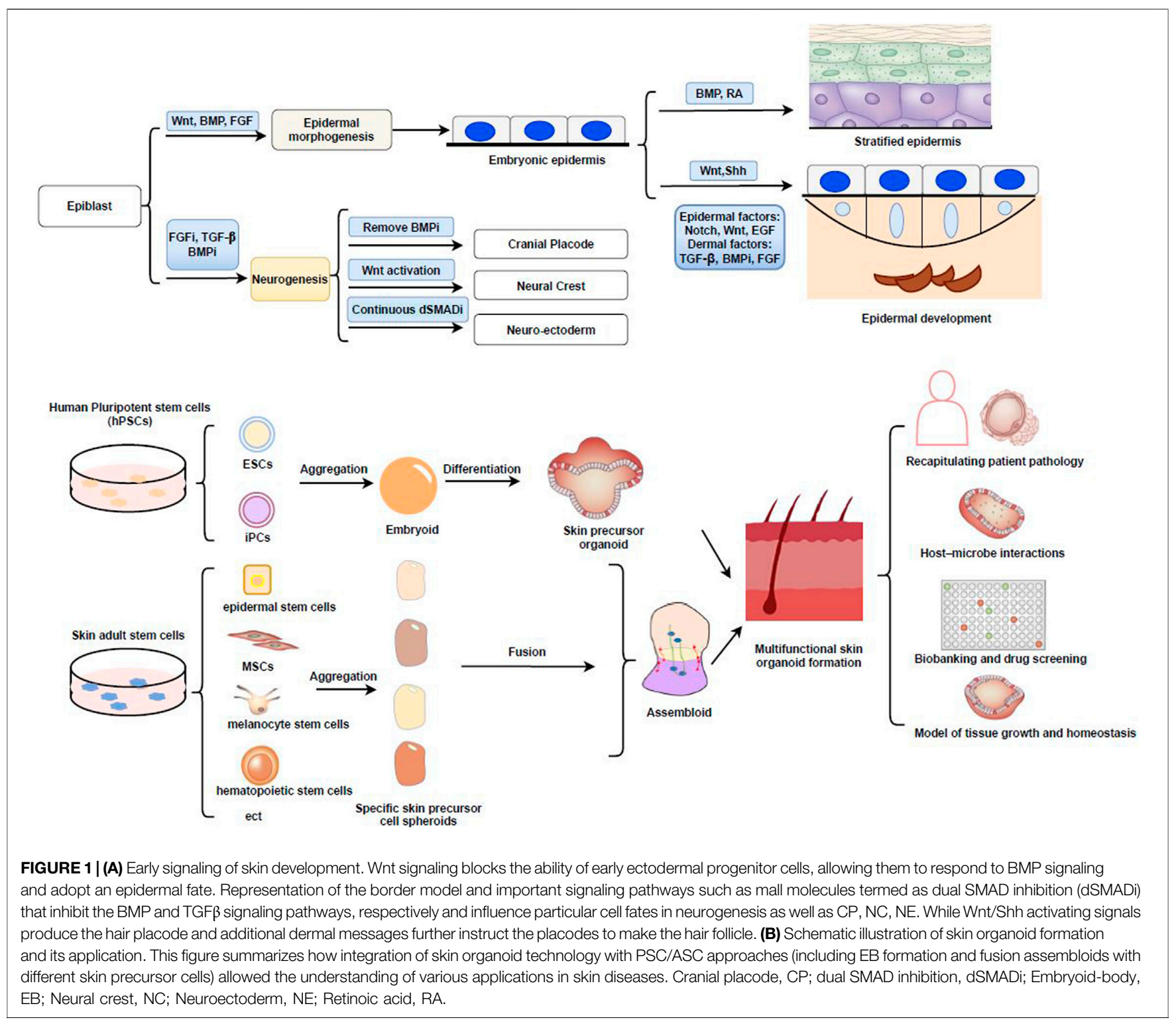

et al., 2018). Skin organoids are derived from hPSCs and can self-assemble to form an organized, skin-like structure composed of skin progenitor cells and hair follicles resembling fetal skin (Lee et al., 2018; Kim and Ju, 2019; Lee et al., 2020).

In this review, we first evaluate recent advances in skin formation in the field of stem cells and regenerative medicine. Then, we discuss the origins of skin cells and skin organoid culture systems and offer feasible suggestions for future directions and methods to generate ideal skin organoids using the latest technologies, such as 3D culture. Despite their tremendous promise, current skin organoid models still have limitations. Therefore, in this review, we also aim to provide an impartial view of the opportunities and challenges relating to skin organoids. Only when current models are fully understood can skin organoids help shed light on our understanding of human skin biology and skin diseases.

\section{SKIN DEVELOPMENT AND MICROENVIRONMENT}

Different types of skin-resident cells perform different functions; thus, we must first fully understand the mechanisms involved in skin development as well as the microenvironment. Importantly, multiple types of skin stem cells, such as epidermal stem cells, as well as other types of progenitor cells that reside in the skin and its appendages (e.g., hair bulbs and sweat glands), are required for the development, continuous renewal, and regeneration of the body's skin, activities that are controlled by the "niches" within the local stem cell microenvironment (Fuchs, 2007; Yin et al., 20132011; Mahmoudi and Brunet, 2012). With the development of genetic and imaging tools, our understanding of the relationship between skin stem cells and their progeny, as well as the interaction between skin stem cells and their niches, has increased over recent years (Gravitz, 2018). Wnt signaling 
emanating from the niches has been proposed to act as a cue for stem cell self-renewal in a variety of mammalian tissues (Clevers et al., 2014) (Figure 1A). At the same time, lineage analysis demonstrated heterogeneity among the cells in stem or progenitor cells are stochastic. In addition, stem cells and their downstream progenitors exploit the full advantages of their own environment according to detailed areas as niches (Ito et al., 2007; Yang et al., 2017). Therefore, skin stem cells, their niches, and associated signals are essential for skin development and differentiation. In addition, the maintenance and function of adult skin stem cells require different microenvironments within the niches, including the presence of a variety of allogeneic cells and associated stem cell lineages (Lane et al., 2014; Gonzales and Fuchs, 2017).

The skin originates from two major tissue types, namely, the ectoderm (epidermis) and mesenchyme (dermis, hypodermis, and mesodermal connective tissue). Sensory nerve endings and melanocytes (neural crest) are also present in the skin (Quarto et al., 2010). In the early embryo, $\mathrm{Wnt} / \beta$-catenin signaling plays a key role in skin development (Siebel and Lendahl, 2017; Lim and Nusse, 2013). During gastrulation, the ectoderm invaginates along the midline for development, and then the ectodermal cells proliferate and migrate downwards from the center (Tchieu et al., 2017). Three primary cell layers (germ layers) are formed in the gastrula: ectoderm, mesoderm, and endoderm. The ectodermal layer lies on the surface of the embryo, and whether or not the ectoderm develops into skin is dependent on Wnt signaling (Fuchs, 2007). In the absence of FGF signaling, ectodermal cells express bone morphogenetic protein (BMP) and develop into epidermis (Tchieu et al., 2017). Additionally, in the absence of Wnt signaling, FGF signaling is activated, BMP expression is weakened, and ectodermal cells can also adopt a neural crest fate (Figure 1A) (Ji et al., 2019; Girgin et al., 2021). By precisely modulating the activities of the FGF, BMP, Wnt, and transforming growth factor $\beta$ (TGF- $\beta$ ) pathways using different substrates and a chemically defined medium, reproducible derivations of neuroectoderm, neural crest, cranial placode, and non-neural ectoderm can be achieved (Tchieu et al., 2017) (Figure 1A).

During early skin development, within several days, cell divisions become first oblique, and then more perpendicular, leading to asymmetric fates, as well as the differentiation and stratification of the epidermis (Matsumura et al., 2021). When morphogenesis is complete, progenitor cells of the epidermis and appendages maintain their contact with the basement membrane and express markers that identify them as keratinocytes (Green et al., 2003).

To conclude, skin formation is a multistep process, involving the growth of the dermis and epidermis, as well as skin appendages. Skin appendages such as hair placodes form from the congregation of $\mathrm{Wnt}^{\text {high }}$ cells in the basal layer (Gonzales and Fuchs, 2017). These cells begin to divide perpendicular to the basement membrane, leading to asymmetrically fated daughters. $\mathrm{Wnt}^{\text {high }}$ cells produce sonic hedgehog (Shh), but only neighboring cells can respond to this signal. Shh signaling induces the underlying mesenchyme to organize into a dermal condensate and simultaneously produce BMP inhibitors. Shh signaling also prompts the covering daughter cells that lose contact with the basement membrane to dampen Wnt signaling ( $\mathrm{Wnt}^{\text {low }}$ ) and divide symmetrically. These $\mathrm{Wnt}^{\text {low }}$ daughters will generate the outer root sheath, which can develop a niche (bulges) of stem cells, while the $\mathrm{Wnt}^{\text {high }}$ daughters may generate the inner root sheath or hair shaft (Hsu and Fuchs, 2012; Gonzales and Fuchs, 2017).

Knowledge about the early stages of human melanocyte and skin appendage fate specification is limited to basic histological studies (Xie et al., 2016; Wang et al., 2020). Lineage tracing using single-cell sequencing has identified important differences in regenerative and developmental strategies among skin stem cells (e.g., bulge stem cells) or normal cells (e.g., adipocytes, melanocytes) (Guerrero-Juarez et al., 2019; Kim et al., 2020; Solé-Boldo et al., 2020). Epithelial and mesenchymal structures form from several types of fate-restricted progenitors. The skin appendage, a functional mini organ, develops in a dynamic environment influenced by a variety of molecular signals (Lim and Nusse, 2013).

Different signaling patterns at different stages of development ensure the growth and progression of the corium and its derivatives (Fuchs, 2007; Hsu and Fuchs, 2012). Every step of epidermal development is closely related to the development of the dermis and the substratum, while differences in the dermis can lead to regional heterogeneity of the overlying epidermis (Zhu et al., 20141004). A variety of cells interact during skin formation (Figure 1A).

\section{SOURCES OF SKIN CELLS AND THE GENERATION OF SKIN ORGANOIDS}

The management of skin defects, both local and full thickness, remains a considerable clinical challenge. The current treatment option consists mainly of medium-thickness skin grafts, but this is constrained by donor site limitations (Meuli et al., 2019). Cell transplantation is a novel treatment that involves isolating cells from small skin biopsies and seeding them in collagen hydrogels (Meuli et al., 2019; Shpichka et al., 2019). While new skin substitutes provide safe coverage of skin defects, traditional skin tissue engineering methods reduce the complexity of skin tissue to two main parts (epidermis and dermis), which does not allow the function of the patient's skin to be reproduced (Weng et al., 2020). Meanwhile, keratinocyte culture in vitro is timeconsuming and labor-intensive, and the generated skin substitutes lack appendages (Tjin et al., 2020; Weng et al., 2020).

Stem cells are the foundation of all mammalian life. The establishment of 3D culture systems (or organoids, where an organ is in a dish) is revolutionizing the way human biology is studied (Kaluthantrige Don and Huch, 2021). Organoids are generated via the 3D culture of isolated tissue progenitor cells or PSCs and need an appropriate environmental background for development (Lei et al., 2017).

Stem cells are the main source of cells for the construction of organoids (Yin et al., 2016). There are two main types of stem cells. One is adult stem cells (ASCs), with each organ having its own specialized ASCs, which usually reside in "niches" that 
TABLE 1 | Overview of current skin organoid methods. A summary of important parameters in skin organoids, including types of stem cells, species, skin organoid identity, source of starting materials, intrinsic patterning or extrinsic signaling molecules, extracellular scaffold and/or bioreactor, whether to use high-throughput sequencing and special considerations for skin modeling. ASCs, Adult stem cells; BMP4, Bone Morphogenetic Protein 4; CDB, Clustering-dependent embryoid body; DP, Dermal papilla; EBs, Embryonic bodies; EEM, Epidermal expansion medium; PSCs, Pluripotent stem cells; RA, Retinoic Acid; TGF- $\beta$ i, TGF- $\beta$ signaling inhibitor; 3D, three-dimensional;

\begin{tabular}{|c|c|c|c|c|c|c|c|c|}
\hline $\begin{array}{l}\text { Types } \\
\text { of stem } \\
\text { cells }\end{array}$ & Species & $\begin{array}{l}\text { Organoid } \\
\text { identity }\end{array}$ & $\begin{array}{l}\text { Starting } \\
\text { cells }\end{array}$ & $\begin{array}{c}\text { Intrinsic } \\
\text { patterning or } \\
\text { extrinsic signaling } \\
\text { molecules }\end{array}$ & $\begin{array}{l}\text { Extracellular } \\
\text { scaffold and/or } \\
\text { bioreactor }\end{array}$ & $\begin{array}{l}\text { High-throughput } \\
\text { analysis }\end{array}$ & $\begin{array}{l}\text { Special considerations } \\
\text { for skin modeling }\end{array}$ & References \\
\hline \multirow[t]{4}{*}{ ASCs } & Mouse & $\begin{array}{l}\text { Murine epidermal } \\
\text { organoid }\end{array}$ & $\begin{array}{l}\text { Murine } \\
\text { epidermal } \\
\text { stem cells }\end{array}$ & $\begin{array}{l}\text { EEM, Noggin, } \\
\text { R-spondin 1, } \\
\text { Forskolin, and FGF1 }\end{array}$ & $\begin{array}{l}\text { Basement } \\
\text { membrane } \\
\text { extract (Cultrex) }\end{array}$ & $\begin{array}{l}\text { Whole mRNA } \\
\text { transcriptome } \\
\text { analysis }\end{array}$ & $\begin{array}{l}\text { Serving as a model to } \\
\text { study adult epidermal } \\
\text { homeostasis and disease } \\
\text { in vitro }\end{array}$ & $\begin{array}{l}\text { Boonekamp } \\
\text { et al. (2019) }\end{array}$ \\
\hline & Human & $\begin{array}{l}\text { Organoid model } \\
\text { of dermal papilla } \\
\text { of human hair } \\
\text { follicle }\end{array}$ & DP fibroblasts & $\begin{array}{l}\text { Contextual human } \\
\text { hair induction assay } \\
\text { using dermal } \\
\text { papillae implanted } \\
\text { into human skin }\end{array}$ & $\begin{array}{l}\text { Cultured as 3D } \\
\text { dermal papilla } \\
\text { fibroblast } \\
\text { spheroids }\end{array}$ & $\begin{array}{l}\text { Affymetrix } \\
\text { microarray } \\
\text { analysis }\end{array}$ & $\begin{array}{l}\text { When grown as } \\
\text { spheroids, human dermal } \\
\text { papilla cells induce de } \\
\text { novo hair follicles in skin }\end{array}$ & $\begin{array}{l}\text { Higgins et al. } \\
\text { (2013) }\end{array}$ \\
\hline & Mouse & $\begin{array}{l}\text { Sweat gland } \\
\text { organoid }\end{array}$ & $\begin{array}{l}\text { Sweat gland } \\
\text { cells }\end{array}$ & $\begin{array}{l}\text { EGF, bFGF, EDA, } \\
\text { TGF- } \beta \mathrm{i}, \mathrm{FSK}, \mathrm{BMP} 4\end{array}$ & $\begin{array}{l}\text { Matrigel tailored } \\
\text { for sweat glands } \\
\text { formed epithelial } \\
\text { organoids }\end{array}$ & NA & $\begin{array}{l}\text { A new strategy for } \\
\text { regenerating functional } \\
\text { sweat gland-like } \\
\text { structures }\end{array}$ & $\begin{array}{l}\text { Diao et al. } \\
(2019)\end{array}$ \\
\hline & Mouse & 3D skin organoid & $\begin{array}{l}\text { Newborn } \\
\text { mouse skin } \\
\text { cells }\end{array}$ & $\begin{array}{l}\text { PKC inhibition } \\
\text { IGF2, VEGF, } \\
\text { Wnt3a, Wnt10b, } \\
\text { and MMP14 }\end{array}$ & $\begin{array}{l}\text { Epidermal cells } \\
\text { and dermal cells } \\
\text { in one droplet }\end{array}$ & $\begin{array}{l}\text { Whole } \\
\text { transcriptome } \\
\text { RNA-seq }\end{array}$ & $\begin{array}{l}\text { Functional perturbation } \\
\text { with inhibitors of the key } \\
\text { molecules at each phase- } \\
\text { transition stage can } \\
\text { suppress or accelerate the } \\
\text { phase-transition process } \\
\text { to form skin }\end{array}$ & Lei et al. (2017) \\
\hline \multirow[t]{4}{*}{ PSCs } & Human & $\begin{array}{l}\text { Induced } \\
\text { pluripotent stem } \\
\text { cell-derived skin } \\
\text { organoid }\end{array}$ & $\begin{array}{l}\text { iPSC-derived } \\
\text { fibroblasts } \\
\text { iPSC-derived } \\
\text { keratinocytes }\end{array}$ & $\begin{array}{l}\text { RA, BMP4, } \\
\text { and EGF. }\end{array}$ & $\begin{array}{l}\text { Embryonic } \\
\text { bodies } \\
\text { Coating with type } \\
\text { I collagen for } \\
\text { fibroblasts } \\
\text { Coating with type } \\
\text { IV collagen } \\
\text { Transwell plate }\end{array}$ & NA & $\begin{array}{l}\text { Using CBMC-iPSCs as a } \\
\text { novel tool for in vitro and in } \\
\text { vivo dermatological } \\
\text { research }\end{array}$ & $\begin{array}{l}\text { Kim et al. } \\
\text { (2018), Kim } \\
\text { and Ju (2019) }\end{array}$ \\
\hline & Mouse & $\begin{array}{l}\text { Integumentary } \\
\text { organ } \\
\text { system (IOS) }\end{array}$ & iPSCs & $\begin{array}{l}\text { A mitomycin } \\
\text { C-treated SNLP } \\
\text { feeder layer } \\
\text { Wnt10b a novel in } \\
\text { vivo transplantation } \\
\text { model }\end{array}$ & $\mathrm{CDB}$ & NA & $\begin{array}{l}\text { Establishing a novel non- } \\
\text { animal assay system, } \\
\text { including appendages } \\
\text { such as hair follicles and } \\
\text { sebaceous glands, for } \\
\text { cosmetics and quasi-drug } \\
\text { testing }\end{array}$ & $\begin{array}{l}\text { Takagi et al. } \\
\text { (2016), } \\
\text { Toyoshima } \\
\text { et al. (2019) }\end{array}$ \\
\hline & Mouse & $\begin{array}{l}\text { PSC-derived skin } \\
\text { organoid }\end{array}$ & ESCs iPSCs & $\begin{array}{l}\text { TGF- } \beta \text { inhibitor } \\
\text { BMP4 } \\
\text { FGF-2 } \\
\text { BMP inhibitor }\end{array}$ & Matrigel & NA & $\begin{array}{l}\text { Studying minimal cellular } \\
\text { and microenvironmental } \\
\text { requirements for hair } \\
\text { follicle induction, } \\
\text { evaluating hair follicle } \\
\text { growth-promoting/ } \\
\text { inhibitory drugs, or } \\
\text { modeling skin diseases }\end{array}$ & $\begin{array}{l}\text { Lee et al. } \\
(2018)\end{array}$ \\
\hline & Human & $\begin{array}{l}\text { Hair-bearing } \\
\text { human skin } \\
\text { organoid }\end{array}$ & ESCs iPSCs & $\begin{array}{l}\text { BMP4 bFGF } \\
\text { TGF } \beta \text { inhibitor } \\
\text { BMP inhibitor }\end{array}$ & $\begin{array}{l}\text { Matrigel } \\
\text { Orbital shaker }\end{array}$ & $\begin{array}{l}\text { Single-cell RNA- } \\
\text { seq to gain insight } \\
\text { into the cell } \\
\text { lineages arising in } \\
\text { skin organoids }\end{array}$ & $\begin{array}{l}\text { Establishing a model for } \\
\text { investigating the cellular } \\
\text { dynamics of developing } \\
\text { human skin and its } \\
\text { appendages }\end{array}$ & $\begin{array}{l}\text { Lee et al. } \\
(2020), \text { Lee } \\
\text { and Koehler } \\
(2021)\end{array}$ \\
\hline
\end{tabular}

provide distinct microenvironments for stem cell maintenance and function (Mahmoudi and Brunet, 2012). The skin contains a variety of ASCs, including epidermal, hair follicle, dermal mesenchymal (MSCs), melanocyte, endothelial, and hematopoietic stem cells, among others (Figure 1B) (Hsu et al., 2014). These ASCs can replace tissue lost through daily attrition, trauma, or disease. Numerous studies have reported on
ASC-derived skin organoids, such as those related to the epidermis, sweat glands, and hair follicles (Higgins et al., 2013; Boonekamp et al., 2019; Diao et al., 2019). In addition, the other type is PSCs, including ESCs and iPSCs (Takahashi and Yamanaka, 2006; Mora et al., 2017). Recent studies have shown that iPSCs can be well controlled and optimized to generate embryoid bodies and then differentiate into 
fibroblasts and keratinocytes under specific condition in the early stage (Kim et al., 2018). However, the derivation of iPSCs by ectopic expression of core pluripotency factors adds the concerns for PSC tumorigenesis (Lee et al., 2013). Cord blood mononuclear cells (CBMCs) have also become a source of replacement cells, and CBMC-derived iPSCs have been differentiated into keratinocytes and fibroblasts, as well as into $3 \mathrm{D}$ skin organoids. The derived keratinocytes and fibroblasts have characteristics similar to those of the original cell lines (Kim and Ju, 2019).

Recently, Lei et al. demonstrated in vitro skin organoids to form skin with hairs from dissociated cells (Lei et al., 2017), while Lee et al. reported a skin organoid culture system that produces complex skin from human PSCs (iPS/ES) (Table 1) (Lee et al., 2020). Within spherical cell aggregates, non-neuroectodermal and neural crest cells were induced by the stepwise regulation of the TGF- $\beta$ and FGF signaling pathways. During the 45 -months incubation period, the existing skin organoid had developed stratified epidermis, fat-rich dermis, and pigmented hair follicles with sebaceous glands. A network of sensory neurons and Schwann cells that formed neuro-like bundles could also be seen. Additionally, when transplanted into nude mice, these organoids formed flat, hairy, and almost completely natural skin.

Skin organoids can produce skin appendages, especially hair follicles, which grow radially and receive innervation from sensory neurons (Lee et al., 2020). Additionally, the hair follicles of skin organoids can reach a level of maturity that is roughly equivalent to second-trimester fetal hair and exhibit the cellular components required for further maturation. However, long-term culture is needed to determine whether xenografted skin organoid-derived follicles can convert to a terminal hair fate or maintain a growth cycle in vivo (Lee et al., 2020).

Capillarization is very important for the development of skin organoids. Recent studies showed that human brain organoids transplanted into the adult mouse brain developed a vasculature and incorporated into local tissues [e.g., blood-brain barrier (BBB)] (Mansour et al., 2018; Grebenyuk and Ranga, 2019). Ebner-Peking et al. reported the 3D self-assembly of adult and induced pluripotent stem cell (iPSC)-derived fibroblasts, keratinocytes, and endothelial progenitors into a novel type of floating spheroid skin organoid. Multi-cell transplant selforganization facilitates the development of skin regeneration strategies using cell suspension transplantation in combination with human platelet factors (Ebner-Peking et al., 2021). We deem that these novel platforms could be leveraged to seed skin organoids with pericytes and endothelial cells, thereby facilitating the investigation of the role of angiogenesis in skin maturation or to derive vascularized skin grafts in the future.

Single-cell RNA sequencing analysis of two strains of PSCderived skin organoids further showed that they came from anatomically different groups of ectodermal cells. Nevertheless, no immune cells, such as Langerhans cells (LCs), were detected in these skin organoids. It is possible to improve our understanding of different cell types and states, as well as their specific pathways, by mining large datasets of single-cell gene expression profiles in this research (Lee et al., 2018; Lee et al., 2020; Lee and Koehler, 2021). A recent single-cell analysis identified new subpopulations of basal cells located at the top or bottom of the reticular dermis and reported that cell fate specification is determined by the expression of lineage-specific transcription factors (Matsumura et al., 2021). Direct reprogramming techniques can convert adult cells from one type to another. The technology of fused assembloids is ripe to build different brain regions in cerebral organoids and this scheme is expected to bring new hope for reasonable source of functional skin (Figure 1B) (Soufi et al., 2012; Iacovides et al., 2016; Qian et al., 2019).

One goal of generating skin organoids is to reconstruct fully functional skin from PSCs or ASCs in vitro. Research has shown that dissociated human fetal skin can reconstitute hair-bearing skin in a nude mouse model because of the specific microenvironment (Yang et al., 2014). Studies on hair follicle generation from hPSCderived cells have relied on complex bioengineering approaches or chimeric methods using human/mouse epidermal/skin cells xenografting onto nude mice to promote skin cell development and folliculogenesis (Lee et al., 2018; Kageyama et al., 2021). The ability to induce substantial vascularization and morphological maturation in skin organoids is conducive to the maturation of skin cells to obtain an adult-like skin (Ebner-Peking et al., 2021). Skin organoids represent a platform for gaining a more in-depth understanding of skin development and formation. Nevertheless, a substantial amount of work must be undertaken to improve the skin organoid system to allow the wide-spread adoption of this technology in this field.

\section{THE APPLICATIONS OF MULTIFUNCTIONAL SKIN ORGANOIDS}

Currently available skin constructs are mainly skin grafts, including cultured epidermal autografts, that can be cultured from skinderived stem cells. They can effectively support skin wound healing and are also a valuable supplement to traditional skin transplantation methods. In addition, combining biomaterials can enhance the stability and functionality of skin grafts. Nevertheless, the high manufacturing costs and lack of skin appendages (e.g., glands, hair) currently limit the therapeutic application of these products (Brockmann et al., 2018; Ebner-Peking et al., 2021). Skin organoids may provide solutions of therapeutic value and clinical applicability of skin grafts and can also be used to identify new regenerative drugs, or for gene therapy. These organoids are similar to primary skin tissues in terms of composition and structure and are easily manipulated and cryopreserved (Boonekamp et al., 2019; Diao et al., 2019). Notably, more complex biotechnologies are currently available, ranging from organoids to multi-physiological systems or organs-on-chips. Some of these models perform at least as well as animal-based models (Park et al., 2019; Horejs, 2021). The overexpression of FOXC1 is sufficient to induce the reprogramming of epidermal cells to functional sweat gland-like cells, which is beneficial for wound healing and sweat gland regeneration (Yao et al., 2019). Furthermore, recent studies have reported the use of cutaneous organ models to investigate the occurrence, development, and resistance to treatment of skin tumors, such as basal cell carcinoma, squamous cell carcinoma, melanoma, and Merkel cell carcinoma (Rebecca et al., 2020). Skin 
organoids could similarly be used for disease modeling applications and drug screening (Yang et al., 2020; Han et al., 2021). Alternatively, patient-sourced or gene-edited donor hiPSCs could be used to simulate inherited skin diseases. For example, genetically modified autologous epidermal cells could provide a lasting treatment for vesicular skin diseases. Several studies have shown that it is possible to correct epidermolysis bullosa, a genetic skin disorder, by CRISPR/Cas9-based targeted genome editing (Itoh et al., 2011; Hirsch et al., 2017; Jacków et al., 2019). hiPSCs can become ideal sources of cells for generating skin organoids. Thus, it is evident that being able to recapitulate skin tissues in a dish has considerably broadened the scope of skin organoid applications, including the study of human skin development, disease modeling, drug testing, investigating skin barrier biology, the development of cell/gene therapies, and toxicological assessments (Niehues et al., 2018; Lee and Koehler, 2021) (Figure 1B).

hiPSC-derived skin organoids can be instantly generated from available spheroids or assembloids (Vogt, 2021) (Figure 1B), allowing their application for high-content screening and drug testing. The push for non-animal testing as laid down in European legislation, particularly regarding European cosmetics regulation, has brought animal-free regulatory testing one step closer. Skin models, such as skin organoids containing a variety of skin structures, could deliver the accuracy required for increased applicability in predicting toxicological effects on the skin (Niehues et al., 2018; Riebeling et al., 2018). Skin organoids might provide novel options for identifying promising targets for future research on the pleiotropic effects of devastating skin injuries sustained in chemical warfare (e.g., resulting from exposure to sulfur mustard) (Rose et al., 2018). Skin organoids generated through the self-organizational abilities of stem/ progenitor cells will aid in the development of new strategies targeting skin regeneration and wound healing (Lee et al., 2020).

The EU H2020 HCA Organoid project has now been launched, aiming to provide a practically useful and readily extensible initial version of the Organoid Cell Atlas within 2 years. The Organoid Cell Atlas represents a basic biology and biomedical application that will enable researchers to functionally dissect and systematically perturb human biological systems, including the skin (Bock et al., 2021). Hence, skin organoids may provide an unprecedented framework to study the molecular and cellular mechanisms of skin biology, including skin diseases, while at the same time opening numerous possibilities for identifying new patientspecific therapeutic approaches.

\section{LIMITATIONS}

Although many challenges have been surmounted, many bottlenecks remain to be overcome, and there is still a large gap between the current state of skin organoid technology and the reality of how these organoids develop and function in the body. First, as the body's first line of defense, the skin is equipped with an impressive array of immune cells, such as LCs. However, it is not enough to simulate the structure of skin, as excluding connective tissues, blood vessels, and immune cells does not allow to recapitulate the physiological environment of normal tissues and organs (Lee et al., 2018; Lee et al., 2020).

Secondly, potential sources of skin cells (e.g., keratinocytes) are scarce, and culturing skin cells in vitro is difficult with current technology (Kim et al., 2018). Cell reprogramming techniques, which can help to regenerate skin cells, are still inefficient in vitro (Chen et al., 2014), and the cells are prone to aging (Mahmoudi and Brunet, 2012). Thus, skin organoid culture systems need to be optimized to allow for their clinical application. Systems for the in vitro culture of potential cells should also continue to be optimized, while more effective reprogramming techniques, such as small molecule-induced chemical reprogramming or genetic reprogramming of genes delivered by biomaterials, should be identified. The $3 \mathrm{D}$ regeneration of skin organoids requires better external safety, including controllability, and internal stability, as well as the non-toxicity of the biological materials used. Additionally, whether the function of regenerated skin organoids is normal and how long they could be maintained in the body also need further investigation. Other problems that need to be overcome include the heterogeneity among cell lines and differences among batches.

\section{SUMMARY AND FUTURE PERSPECTIVES}

To conclude, stem and progenitor cells have great potential for future cell transplantation applications and may prove to be a sustainable alternative source of skin cells. Although the production of PSCs is time-consuming and laborious, HLA homozygous iPS cells have been proposed as an alternative way to solve this problem, in that a small number of cells can be used in large numbers of patients (Okita et al., 2011; Xu et al., 2019). In addition, 3D bioprinting technology enables a much more precise simulation of biophysical properties, including organoid size, cell number, and conformation, and modification of the latter can substantially increase starting cell numbers (Lawlor et al., 2021). Although many problems and obstacles remain, patient-derived organoids should further improve our understanding of disease and heterogeneity in patients, which may lead to personalized therapies for the treatment of a variety of diseases (Dutta et al., 2017).

The generation of skin organoids represents a new hope for skin regeneration and is expected to provide a novel scheme for the diagnosis and treatment of skin diseases. Skin organoids can be used to investigate physiological functions, such as cutaneous nerve sensation and microbiome-skin interactions, as well as for exploratory research into models of cutaneous viral-bacterial coinfections, makeup testing, and high-throughput drug screening (Figure 1B). Overall, we believe that skin organoids represent a huge breakthrough that should facilitate the advancement of both basic and clinical research.

\section{AUTHOR CONTRIBUTIONS}

This review paper was written by HS, revised by $\mathrm{Y}-\mathrm{XZ}$, and guided by Y-ML. 


\section{FUNDING}

This work was supported by the National Natural Science Foundation of the People's Republic of China (Grant Nos 81573053).

\section{REFERENCES}

Bock, C., Boutros, M., Boutros, M., Camp, J. G., Clarke, L., Clevers, H., et al. (2021). The Organoid Cell Atlas. Nat. Biotechnol. 39 (1), 13-17. Epub 2021/01/ 02PubMed PMID: 33384458; PubMed Central PMCID: PMCPMC7801253. doi:10.1038/s41587-020-00762-x

Boonekamp, K. E., Kretzschmar, K., Wiener, D. J., Asra, P., Derakhshan, S., Puschhof, J., et al. (2019). Long-term Expansion and Differentiation of Adult Murine Epidermal Stem Cells in 3D Organoid Cultures. Proc. Natl. Acad. Sci. USA 116 (29), 14630-14638. Epub 2019/06/30PubMed PMID: 31253707; PubMed Central PMCID: PMCPMC6642409. doi:10.1073/ pnas. 1715272116

Brockmann, I., Ehrenpfordt, J., Sturmheit, T., Brandenburger, M., Kruse, C., Zille, M., et al. (2018). Skin-Derived Stem Cells for Wound Treatment Using Cultured Epidermal Autografts: Clinical Applications and Challenges. Stem Cell Int. 2018, 1-9. Epub 2018/05/17PubMed PMID: 29765411; PubMed Central PMCID: PMCPMC5889868. doi:10.1155/2018/4623615

Chen, Y. E., Fischbach, M. A., and Belkaid, Y. (2018). Skin Microbiota-Host Interactions. Nature 553 (7689), 427-436. Epub 2018/01/25PubMed PMID: 29364286; PubMed Central PMCID: PMCPMC6075667. doi:10.1038/ nature 25177

Chen, Y., Mistry, D. S., and Sen, G. L. (2014). Highly Rapid and Efficient Conversion of Human Fibroblasts to Keratinocyte-like Cells. J. Invest. Dermatol. 134 (2), 335-344. Epub 2013/08/08PubMed PMID: 23921950; PubMed Central PMCID: PMCPMC3875612. doi:10.1038/jid.2013.327

Clevers, H., Loh, K. M., and Nusse, R. (2014). An Integral Program for Tissue Renewal and Regeneration: Wnt Signaling and Stem Cell Control. Science, 346(6205). New York, NY, 1248012. Epub 2014/10/04PubMed PMID: 25278615. doi:10.1126/science. 1248012

Diao, J., Liu, J., Wang, S., Chang, M., Wang, X., Guo, B., et al. (2019). Sweat Gland Organoids Contribute to Cutaneous Wound Healing and Sweat Gland Regeneration. Cell Death Dis 10 (3), 238. Epub 2019/03/13PubMed PMID: 30858357; PubMed Central PMCID: PMCPMC6411741. doi:10.1038/s41419019-1485-5

Dutta, D., Heo, I., and Clevers, H. (2017). Disease Modeling in Stem Cell-Derived 3D Organoid Systems. Trends Mol. Med. 23 (5), 393-410. Epub 2017/03/ 28PubMed PMID: 28341301. doi:10.1016/j.molmed.2017.02.007

Ebner-Peking, P., Krisch, L., Wolf, M., Hochmann, S., Hoog, A., Vári, B., et al. (2021). Self-assembly of Differentiated Progenitor Cells Facilitates Spheroid Human Skin Organoid Formation and Planar Skin Regeneration. Theranostics 11 (17), 8430-8447. Epub 2021/08/11PubMed PMID: 34373751; PubMed Central PMCID: PMCPMC8344006. doi:10.7150/thno.59661

Fuchs, E. (2007). Scratching the Surface of Skin Development. Nature 445 (7130), 834-842. Epub 2007/02/23PubMed PMID: 17314969; PubMed Central PMCID: PMCPMC2405926. doi:10.1038/nature05659

Girgin, M. U., Broguiere, N., Mattolini, L., and Lutolf, M. P. (2021). Gastruloids Generated without Exogenous Wnt Activation Develop Anterior Neural Tissues. Stem Cel. Rep. 16, 1143-1155. Epub 2021/04/24PubMed PMID: 33891872. doi:10.1016/j.stemcr.2021.03.017

Gonzales, K. A. U., and Fuchs, E. (2017). Skin and its Regenerative Powers: An Alliance between Stem Cells and Their Niche. Dev. Cel. 43 (4), 387-401. Epub 2017/11/22PubMed PMID: 29161590; PubMed Central PMCID: PMCPMC5797699. doi:10.1016/j.devcel.2017.10.001

Gravitz, L. (2018). Skin. Nature 563 (7732), S83. Epub 2018/11/23PubMed PMID: 30464282. doi:10.1038/d41586-018-07428-4

Grebenyuk, S., and Ranga, A. (2019). Engineering Organoid Vascularization. Front. Bioeng. Biotechnol. 7, 39. Epub 2019/04/04PubMed PMID: 30941347; PubMed Central PMCID: PMCPMC6433749. doi:10.3389/fbioe.2019.00039

\section{ACKNOWLEDGMENTS}

The authors would like to thank Yun-Wen Zheng and Li-Ping Liu for discussions about the idea, Meng-Xue Xu for proofreading the draft.

Green, H., Easley, K., and Iuchi, S. (2003). Marker Succession during the Development of Keratinocytes from Cultured Human Embryonic Stem Cells. Proc. Natl. Acad. Sci. 100 (26), 15625-15630. Epub 2003/12/ 10PubMed PMID: 14663151; PubMed Central PMCID: PMCPMC307618. doi:10.1073/pnas.0307226100

Guerrero-Juarez, C. F., Dedhia, P. H., Jin, S., Ruiz-Vega, R., Ma, D., Liu, Y., et al. (2019). Single-cell Analysis Reveals Fibroblast Heterogeneity and MyeloidDerived Adipocyte Progenitors in Murine Skin Wounds. Nat. Commun. 10 (1), 650. Epub 2019/02/10PubMed PMID: 30737373; PubMed Central PMCID: PMCPMC6368572. doi:10.1038/s41467-018-08247-X

Han, Y., Duan, X., Yang, L., Nilsson-Payant, B. E., Wang, P., Duan, F., et al. (2021). Identification of SARS-CoV-2 Inhibitors Using Lung and Colonic Organoids. Nature 589 (7841), 270-275. Epub 2020/10/30PubMed PMID: 33116299; PubMed Central PMCID: PMCPMC8034380. doi:10.1038/s41586-020-2901-9

Higgins, C. A., Chen, J. C., Cerise, J. E., Jahoda, C. A. B., and Christiano, A. M. (2013). Microenvironmental Reprogramming by Three-Dimensional Culture Enables Dermal Papilla Cells to Induce De Novo Human Hair-Follicle Growth. Proc. Natl. Acad. Sci. 110 (49), 19679-19688. Epub 2013/10/23PubMed PMID: 24145441; PubMed Central PMCID: PMCPMC3856847. doi:10.1073/ pnas. 1309970110

Hirsch, T., Rothoeft, T., Teig, N., Bauer, J. W., Pellegrini, G., De Rosa, L., et al. (2017). Regeneration of the Entire Human Epidermis Using Transgenic Stem Cells. Nature 551 (7680), 327-332. Epub 2017/11/17PubMed PMID: 29144448; PubMed Central PMCID: PMCPMC6283270. doi:10.1038/nature24487

Horejs, C. (2021). Organ Chips, Organoids and the Animal Testing Conundrum. Nat. Rev. Mater. 6, 372-373. PubMed PMID: 33936776; PubMed Central PMCID: PMCPMC8072732. Epub 2021/05/04. doi:10.1038/s41578-02100313-Z

Hsu, Y.-C., and Fuchs, E. (2012). A Family Business: Stem Cell Progeny Join the Niche to Regulate Homeostasis. Nat. Rev. Mol. Cel Biol 13 (2), 103-114. Epub 2012/01/24PubMed PMID: 22266760; PubMed Central PMCID: PMCPMC3280338. doi:10.1038/nrm3272

Hsu, Y.-C., Li, L., and Fuchs, E. (2014). Emerging Interactions between Skin Stem Cells and Their Niches. Nat. Med. 20 (8), 847-856. Epub 2014/08/08PubMed PMID: 25100530; PubMed Central PMCID: PMCPMC4358898. doi:10.1038/ nm.3643

Iacovides, D., Rizki, G., Lapathitis, G., and Strati, K. (2016). Direct Conversion of Mouse Embryonic Fibroblasts into Functional Keratinocytes through Transient Expression of Pluripotency-Related Genes. Stem Cel Res Ther 7 (1), 98. Epub 2016/07/31PubMed PMID: 27473056; PubMed Central PMCID: PMCPMC4966867. doi:10.1186/s13287-016-0357-5

Ito, M., Yang, Z., Andl, T., Cui, C., Kim, N., Millar, S. E., et al. (2007). Wntdependent De Novo Hair Follicle Regeneration in Adult Mouse Skin after Wounding. Nature 447 (7142), 316-320. Epub 2007/05/18PubMed PMID: 17507982. doi: $10.1038 /$ nature 05766

Itoh, M., Kiuru, M., Cairo, M. S., and Christiano, A. M. (2011). Generation of Keratinocytes from normal and Recessive Dystrophic Epidermolysis BullosaInduced Pluripotent Stem Cells. Proc. Natl. Acad. Sci. 108 (21), 8797-8802. Epub 2011/05/11PubMed PMID: 21555586; PubMed Central PMCID: PMCPMC3102348. doi:10.1073/pnas.1100332108

Jacków, J., Guo, Z., Hansen, C., Abaci, H. E., Doucet, Y. S., Shin, J. U., et al. (2019). CRISPR/Cas9-based Targeted Genome Editing for Correction of Recessive Dystrophic Epidermolysis Bullosa Using iPS Cells. Proc. Natl. Acad. Sci. USA 116 (52), 26846-26852. Epub 2019/12/11PubMed PMID: 31818947; PubMed Central PMCID: PMCPMC6936361. doi:10.1073/pnas.1907081116

Ji, Y., Hao, H., Reynolds, K., McMahon, M., and Zhou, C. J. (2019). Wnt Signaling in Neural Crest Ontogenesis and Oncogenesis. Cells 8 (10), 1173. Epub 2019/10/ 02, PubMed PMID: 31569501; PubMed Central PMCID: PMCPMC6829301. doi:10.3390/cells 8101173 
Kageyama, T., Chun, Y.-S., and Fukuda, J. (2021). Hair Follicle Germs Containing Vascular Endothelial Cells for Hair Regenerative Medicine. Sci. Rep. 11 (1), 624. Epub 2021/01/14PubMed PMID: 33436760; PubMed Central PMCID: PMCPMC7804392. doi:10.1038/s41598-020-79722-z

Kaluthantrige Don, F., and Huch, M. (2021). Organoids, where We Stand and where We Go. Trends Mol. Med. 27, 416-418. doi:10.1016/ j.molmed.2021.03.001

Kim, D., Chung, K. B., and Kim, T.-G. (2020). Application of Single-Cell RNA Sequencing on Human Skin: Technical Evolution and Challenges. J. Dermatol. Sci. 99 (2), 74-81. Epub 2020/07/01PubMed PMID: 32593488. doi:10.1016/ j.jdermsci.2020.06.002

Kim, Y., and Ju, J. H. (2019). Generation of 3D Skin Organoid from Cord BloodDerived Induced Pluripotent Stem Cells. JoVE (146). Epub 2019/05/07PubMed PMID: 31058887. doi:10.3791/59297

Kim, Y., Park, N., Rim, Y. A., Nam, Y., Jung, H., Lee, K., et al. (2018). Establishment of a Complex Skin Structure via Layered Co-culture of Keratinocytes and Fibroblasts Derived from Induced Pluripotent Stem Cells. Stem Cel Res Ther 9 (1), 217. Epub 2018/08/15PubMed PMID: 30103800; PubMed Central PMCID: PMCPMC6090613. doi:10.1186/s13287-018-0958-2

Lane, S. W., Williams, D. A., and Watt, F. M. (2014). Modulating the Stem Cell Niche for Tissue Regeneration. Nat. Biotechnol. 32 (8), 795-803. Epub 2014/08/ 06PubMed PMID: 25093887; PubMed Central PMCID: PMCPMC4422171. doi:10.1038/nbt.2978

Lawlor, K. T., Vanslambrouck, J. M., Higgins, J. W., Chambon, A., Bishard, K., Arndt, D., et al. (2021). Cellular Extrusion Bioprinting Improves Kidney Organoid Reproducibility and Conformation. Nat. Mater. 20 (2), 260-271. Epub 2020/11/25PubMed PMID: 33230326; PubMed Central PMCID: PMCPMC7855371. doi:10.1038/s41563-020-00853-9

Lee, A. S., Tang, C., Rao, M. S., Weissman, I. L., and Wu, J. C. (2013). Tumorigenicity as a Clinical Hurdle for Pluripotent Stem Cell Therapies. Nat. Med. 19 (8), 998-1004. Epub 2013/08/08PubMed PMID: 23921754; PubMed Central PMCID: PMCPMC3967018. doi:10.1038/nm.3267

Lee, J., Böscke, R., Tang, P.-C., Hartman, B. H., Heller, S., and Koehler, K. R. (2018). Hair Follicle Development in Mouse Pluripotent Stem Cell-Derived Skin Organoids. Cel Rep. 22 (1), 242-254. Epub 2018/01/04PubMed PMID: 29298425; PubMed Central PMCID: PMCPMC5806130. doi:10.1016/ j.celrep.2017.12.007

Lee, J., and Koehler, K. R. (2021). Skin Organoids: A New Human Model for Developmental and Translational Research. Exp. Dermatol. 30 (4), 613-620. Epub 2021/01/29PubMed PMID: 33507537. doi:10.1111/exd.14292

Lee, J., Rabbani, C. C., Gao, H., Steinhart, M. R., Woodruff, B. M., Pflum, Z. E., et al. (2020). Hair-bearing Human Skin Generated Entirely from Pluripotent Stem Cells. Nature 582 (7812), 399-404. Epub 2020/06/05PubMed PMID: 32494013; PubMed Central PMCID: PMCPMC7593871. doi:10.1038/s41586-020-2352-3

Lei, M., Schumacher, L. J., Lai, Y.-C., Juan, W.-T., Yeh, C.-Y., Wu, P., et al. (2017). Self-organization Process in Newborn Skin Organoid Formation Inspires Strategy to Restore Hair Regeneration of Adult Cells. Proc. Natl. Acad. Sci. USA 114 (34), E7101-E7110. Epub 2017/08/12PubMed PMID: 28798065; PubMed Central PMCID: PMCPMC5576784. doi:10.1073/pnas.1700475114

Lim, X., and Nusse, R. (2013). Wnt Signaling in Skin Development, Homeostasis, and Disease. Cold Spring Harbor Perspect. Biol. 5 (2), a008029. Epub 2012/12/ 05PubMed PMID: 23209129; PubMed Central PMCID: PMCPMC3552514. doi:10.1101/cshperspect.a008029

Mahmoudi, S., and Brunet, A. (2012). Aging and Reprogramming: a Two-Way Street. Curr. Opin. Cel. Biol. 24 (6), 744-756. Epub 2012/11/14PubMed PMID: 23146768; PubMed Central PMCID: PMCPMC3540161. doi:10.1016/ j.ceb.2012.10.004

Mansour, A. A., Gonçalves, J. T., Bloyd, C. W., Li, H., Fernandes, S., Quang, D., et al. (2018). An In Vivo Model of Functional and Vascularized Human Brain Organoids. Nat. Biotechnol. 36 (5), 432-441. Epub 2018/04/17PubMed PMID: 29658944; PubMed Central PMCID: PMCPMC6331203. doi:10.1038/nbt.4127

Matsumura, H., Liu, N., Nanba, D., Ichinose, S., Takada, A., Kurata, S., et al. (2021). Distinct Types of Stem Cell Divisions Determine Organ Regeneration and Aging in Hair Follicles. Nat. Aging 1 (2), 190-204. doi:10.1038/s43587-02100033-7

Meuli, M., Hartmann-Fritsch, F., Hüging, M., Marino, D., Saglini, M., Hynes, S., et al. (2019). A Cultured Autologous Dermo-Epidermal Skin Substitute for Full-
Thickness Skin Defects. Plast. Reconstr. Surg. 144 (1), 188-198. Epub 2019/06/ 28PubMed PMID: 31246829. doi:10.1097/prs.0000000000005746

Mora, C., Serzanti, M., Consiglio, A., Memo, M., and Dell'Era, P. (2017). Clinical Potentials of Human Pluripotent Stem Cells. Cell Biol Toxicol 33 (4), 351-360. Epub 2017/02/09PubMed PMID: 28176010. doi:10.1007/s10565-017-9384-y

Niehues, H., Bouwstra, J. A., El Ghalbzouri, A., Brandner, J. M., Zeeuwen, P. L. J. M., and van den Bogaard, E. H. (2018). 3D Skin Models for 3R Research: The Potential of 3D Reconstructed Skin Models to Study Skin Barrier Function. Exp. Dermatol. 27 (5), 501-511. Epub 2018/03/09PubMed PMID: 29518287. doi:10.1111/exd.13531

Okita, K., Matsumura, Y., Sato, Y., Okada, A., Morizane, A., Okamoto, S., et al. (2011). A More Efficient Method to Generate Integration-free Human iPS Cells. Nat. Methods 8 (5), 409-412. Epub 2011/04/05PubMed PMID: 21460823. doi:10.1038/nmeth.1591

Park, S. E., Georgescu, A., and Huh, D. (2019). Organoids-on-a-chip. Science, 364(6444). New York, NY, 960-965. Epub 2019/06/07PubMed PMID: 31171693; PubMed Central PMCID: PMCPMC7764943. doi:10.1126/ science.aaw7894

Qian, X., Song, H., and Ming, G.-l. (2019). Brain Organoids: Advances, Applications and Challenges. Development, 146(8). Cambridge, England. Epub 2019/04/18PubMed PMID: 30992274; PubMed Central PMCID: PMCPMC6503989. doi:10.1242/dev.166074

Quarto, N., Wan, D. C., Kwan, M. D., Panetta, N. J., Li, S., and Longaker, M. T. (2010). Origin Matters: Differences in Embryonic Tissue Origin and Wnt Signaling Determine the Osteogenic Potential and Healing Capacity of Frontal and Parietal Calvarial Bones. J. Bone Mineral Res. 25 (7), 091123192917092-42. Epub 2009/11/26PubMed PMID: 19929441; PubMed Central PMCID: PMCPMC3154006. doi:10.1359/jbmr.091116

Rebecca, V. W., Somasundaram, R., and Herlyn, M. (2020). Pre-clinical Modeling of Cutaneous Melanoma. Nat. Commun. 11 (1), 2858. Epub 2020/06/ 07PubMed PMID: 32504051; PubMed Central PMCID: PMCPMC7275051. doi:10.1038/s41467-020-15546-9

Riebeling, C., Luch, A., and Tralau, T. (2018). Skin Toxicology and 3Rs-Current Challenges for Public Health protection. Exp. Dermatol. 27 (5), 526-536. Epub 2018/03/27PubMed PMID: 29575089. doi:10.1111/exd.13536

Rose, D., Schmidt, A., Brandenburger, M., Sturmheit, T., Zille, M., and Boltze, J. (2018). Sulfur Mustard Skin Lesions: A Systematic Review on Pathomechanisms, Treatment Options and Future Research Directions. Toxicol. Lett. 293, 82-90. Epub 2017/12/06PubMed PMID: 29203275. doi:10.1016/j.toxlet.2017.11.039

Rossi, G., Manfrin, A., and Lutolf, M. P. (2018). Progress and Potential in Organoid Research. Nat. Rev. Genet. 19 (11), 671-687. Epub 2018/09/20PubMed PMID: 30228295. doi:10.1038/s41576-018-0051-9

Shi, Y., Inoue, H., Wu, J. C., and Yamanaka, S. (2017). Induced Pluripotent Stem Cell Technology: a Decade of Progress. Nat. Rev. Drug Discov. 16 (2), 115-130. Epub 2016/12/17PubMed PMID: 27980341; PubMed Central PMCID: PMCPMC6416143. doi:10.1038/nrd.2016.245

Shpichka, A., Butnaru, D., Bezrukov, E. A., Sukhanov, R. B., Atala, A., Burdukovskii, V., et al. (2019). Skin Tissue Regeneration for Burn Injury. Stem Cel Res Ther 10 (1), 94. Epub 2019/03/17PubMed PMID: 30876456; PubMed Central PMCID: PMCPMC6419807. doi:10.1186/s13287-019-1203-3

Siebel, C., and Lendahl, U. (2017). Notch Signaling in Development, Tissue Homeostasis, and Disease. Physiol. Rev. 97 (4), 1235-1294. Epub 2017/08/ 11PubMed PMID: 28794168. doi:10.1152/physrev.00005.2017

Solé-Boldo, L., Raddatz, G., Schütz, S., Mallm, J.-P., Rippe, K., Lonsdorf, A. S., et al. (2020). Single-cell Transcriptomes of the Human Skin Reveal Age-Related Loss of Fibroblast Priming. Commun. Biol. 3 (1), 188. Epub 2020/04/25PubMed PMID: 32327715; PubMed Central PMCID: PMCPMC7181753 financial interests: F.L. received consultation fees from Beiersdorf AG. The other authors have no competing financial interests. doi:10.1038/s42003-020-0922-4

Soufi, A., Donahue, G., and Zaret, K. S. (2012). Facilitators and Impediments of the Pluripotency Reprogramming Factors' Initial Engagement with the Genome. Cell 151 (5), 994-1004. Epub 2012/11/20PubMed PMID: 23159369; PubMed Central PMCID: PMCPMC3508134. doi:10.1016/j.cell.2012.09.045

Takagi, R., Ishimaru, J., Sugawara, A., Toyoshima, K.-e., Ishida, K., Ogawa, M., et al. (2016). Bioengineering a 3D Integumentary Organ System from iPS Cells Using an In Vivo Transplantation Model. Sci. Adv. 2 (4), e1500887. Epub 2016/04/ 
07PubMed PMID: 27051874; PubMed Central PMCID: PMCPMC4820374. doi:10.1126/sciadv.1500887

Takahashi, K., Tanabe, K., Ohnuki, M., Narita, M., Ichisaka, T., Tomoda, K., et al. (2007). Induction of Pluripotent Stem Cells from Adult Human Fibroblasts by Defined Factors. Cell 131 (5), 861-872. Epub 2007/11/24PubMed PMID: 18035408. doi:10.1016/j.cell.2007.11.019

Takahashi, K., and Yamanaka, S. (2006). Induction of Pluripotent Stem Cells from Mouse Embryonic and Adult Fibroblast Cultures by Defined Factors. Cell 126 (4), 663-676. Epub 2006/08/15PubMed PMID: 16904174. doi:10.1016/ j.cell.2006.07.024

Takeo, M., Lee, W., and Ito, M. (2015). Wound Healing and Skin Regeneration. Cold Spring Harbor Perspect. Med. 5 (1), a023267. Epub 2015/01/07PubMed PMID: 25561722; PubMed Central PMCID: PMCPMC4292081. doi:10.1101/ cshperspect.a023267

Tchieu, J., Zimmer, B., Fattahi, F., Amin, S., Zeltner, N., Chen, S., et al. (2017). A Modular Platform for Differentiation of Human PSCs into All Major Ectodermal Lineages. Cell stem cell 21 (3), 399-410. e7. Epub 2017/09/ 09PubMed PMID: 28886367; PubMed Central PMCID: PMCPMC5737635. doi:10.1016/j.stem.2017.08.015

Tiin, M. S., Chua, A. W. C., and Tryggvason, K. (2020). Chemically Defined and Xenogeneic-free Culture Method for Human Epidermal Keratinocytes on Laminin-Based Matrices. Nat. Protoc. 15 (2), 694-711. Epub 2020/01/ 17PubMed PMID: 31942079. doi:10.1038/s41596-019-0270-3

Toyoshima, K.-e., Ogawa, M., and Tsuji, T. (2019). Regeneration of a Bioengineered 3D Integumentary Organ System from iPS Cells. Nat. Protoc. 14 (5), 1323-1338. Epub 2019/04/10PubMed PMID: 30962607. doi:10.1038/ s41596-019-0124-z

Vogt, N. (2021). Assembloids. Nat. Methods 18 (1), 27. Epub 2021/01/08PubMed PMID: 33408387. doi:10.1038/s41592-020-01026-x

Wang, S., Drummond, M. L., Guerrero-Juarez, C. F., Tarapore, E., MacLean, A. L., Stabell, A. R., et al. (2020). Single Cell Transcriptomics of Human Epidermis Identifies Basal Stem Cell Transition States. Nat. Commun. 11 (1), 4239. Epub 2020/08/28PubMed PMID: 32843640; PubMed Central PMCID: PMCPMC7447770. doi:10.1038/s41467-020-18075-7

Weng, T., Wu, P., Zhang, W., Zheng, Y., Li, Q., Jin, R., et al. (2020). Regeneration of Skin Appendages and Nerves: Current Status and Further Challenges. J. Transl Med. 18 (1), 53. Epub 2020/02/06PubMed PMID: 32014004; PubMed Central PMCID: PMCPMC6996190. doi:10.1186/s12967-020-02248-5

Xie, J., Yao, B., Han, Y., Huang, S., and Fu, X. (2016). Skin Appendage-Derived Stem Cells: Cell Biology and Potential for Wound Repair. Burns \& trauma 4, 38. Epub 2016/11/02PubMed PMID: 27800498; PubMed Central PMCID: PMCPMC5082359. doi:10.1186/s41038-016-0064-6

Xu, H., Wang, B., Ono, M., Kagita, A., Fujii, K., Sasakawa, N., et al. (2019). Targeted Disruption of HLA Genes via CRISPR-Cas9 Generates iPSCs with Enhanced Immune Compatibility. Cell stem cell 24 (4), 566-578. e7. Epub 2019/03/ 12PubMed PMID: 30853558. doi:10.1016/j.stem.2019.02.005

Yang, H., Adam, R. C., Ge, Y., Hua, Z. L., and Fuchs, E. (2017). EpithelialMesenchymal Micro-niches Govern Stem Cell Lineage Choices. Cell 169 (3),
483-496. e13. Epub 2017/04/18PubMed PMID: 28413068; PubMed Central PMCID: PMCPMC5510744. doi:10.1016/j.cell.2017.03.038

Yang, L., Han, Y., Nilsson-Payant, B. E., Gupta, V., Wang, P., Duan, X., et al. (2020). A Human Pluripotent Stem Cell-Based Platform to Study SARS-CoV2 Tropism and Model Virus Infection in Human Cells and Organoids. Cell stem cell 27 (1), 125-136. e7. Epub 2020/06/25PubMed PMID: 32579880; PubMed Central PMCID: PMCPMC7303620. doi:10.1016/ j.stem.2020.06.015

Yang, R., Zheng, Y., Burrows, M., Liu, S., Wei, Z., Nace, A., et al. (2014). Generation of Folliculogenic Human Epithelial Stem Cells from Induced Pluripotent Stem Cells. Nat. Commun. 5, 3071. Epub 2014/01/29PubMed PMID: 24468981; PubMed Central PMCID: PMCPMC4049184. doi:10.1038/ ncomms 4071

Yao, B., Xie, J., Liu, N., Hu, T., Song, W., Huang, S., et al. (2019). Direct Reprogramming of Epidermal Cells toward Sweat Gland-like Cells by Defined Factors. Cel Death Dis 10 (4), 272. Epub 2019/03/22PubMed PMID: 30894517; PubMed Central PMCID: PMCPMC6426881. doi:10.1038/ s41419-019-1503-7

Yin, H., Price, F., and Rudnicki, M. A. (20132011). Satellite Cells and the Muscle Stem Cell Niche. Physiol. Rev. 93 (1), 23-67. Epub 2013/01/11PubMed PMID: 23303905; PubMed Central PMCID: PMCPMC4073943. doi:10.1152/ physrev.0004310.1152/physrev.00043.2011

Yin, X., Mead, B. E., Safaee, H., Langer, R., Karp, J. M., and Levy, O. (2016). Engineering Stem Cell Organoids. Cell stem cell 18 (1), 25-38. Epub 2016/01/ 11PubMed PMID: 26748754; PubMed Central PMCID: PMCPMC4728053. doi:10.1016/j.stem.2015.12.005

Zhu, X.-J., Liu, Y., Dai, Z.-M., Zhang, X., Yang, X., Li, Y., et al. (201410046). BMPFGF Signaling axis Mediates Wnt-Induced Epidermal Stratification in Developing Mammalian Skin. Plos Genet. 10 (10), e1004687. Epub 2014/10/ 21PubMed PMID: 25329657; PubMed Central PMCID: PMCPMC4199507. doi:10.1371/journal.pgen10.1371/journal.pgen.1004687

Conflict of Interest: The authors declare that the research was conducted in the absence of any commercial or financial relationships that could be construed as a potential conflict of interest.

Publisher's Note: All claims expressed in this article are solely those of the authors and do not necessarily represent those of their affiliated organizations, or those of the publisher, the editors and the reviewers. Any product that may be evaluated in this article, or claim that may be made by its manufacturer, is not guaranteed or endorsed by the publisher.

Copyright $\odot 2021$ Sun, Zhang and Li. This is an open-access article distributed under the terms of the Creative Commons Attribution License (CC BY). The use, distribution or reproduction in other forums is permitted, provided the original author(s) and the copyright owner(s) are credited and that the original publication in this journal is cited, in accordance with accepted academic practice. No use, distribution or reproduction is permitted which does not comply with these terms. 